Doc. dr. Nusreta Kepeš ${ }^{1}$

\title{
ETIOLOGIJA POREMEĆAJA PONAŠANJA KOD ADOLESCENATA U BIH
}

\section{Sažetak}

BiH drustvo je zadnjïh godina suočeno sa pojavom drustveno nepribvatlivog ponašanja kod maloljetnika koje iz. dana u dan poprima sve veće razmjere. Ovaj rad je samo jedan mali i skeromni doprinos u rasvjetljavanju ovog problem, a buduci da na egzaktan način analizira njegovu pojavnost $i$ etiologiju. Sustina istraživanja jeste da se na osnovu uturdenog faktičkog stanja u školama dodatno analizira, sistematizuje $i$ iqurši komparacija uaročno-posljedicnih faktora nastanka društveno nepribvatljivog ponašanja kod učenika. Dobiveni rezultati mogu poslǔ̌iti u pronalařenju adekvatnih strategija koje bi dale trajne $i$ ucinkovite requltate u prevalenciji poreméaja ponašanja kod učenika osnounih i srednjïh škola.

\section{Problem društveno neprihvatljivih oblika ponašanja kod adolescenata}

Statistika u Evropi govori da je svako treće krivično djelo počinio maloljetnik koji se u kasnijoj dobi, u skoro 95\% slučajeva, oda kriminalu. Popularni magazini Der Spiegel i Stern vrlo često u svojim izvještajima pišu o nasilju među mladima u Evropi koje se manifestuje u raznim destruktivnim oblicima, kao što je ubijanje svojih vršnjaka, hladnokrvno mučenje kućnih ljubimaca, razna barbarska razaranja uz posjedovanje i upotrebu oružja, učestala silovanja, konzumiranja opojnih droga i alkohola u školama, te mnogim drugim devijantnim radnjama (Henting, H.,1997:11). Bosna i Hercegovina se sve više susreće sa sličnim vidovima društveno neprihvatljivog ponašanja kod djece i mladih. Iako je teško tvrditi da je stopa maloljetničkog kriminala u našoj zemlji u porastu, činjenice govore da su problemi maloljetničkog krivičnog pravosuđa izuzetno izraženi. Ukupno ekonomsko i političko stanje u Bosni i Hercegovini objektivno pogoduje porastu socijalno-devijantnih i patoloških pojava u društvu koje znatno utječu i na pojavu maloljetničkog prijestupništva. $\mathrm{Na}$ osnovu ovogodišnjih podataka o stanju i kretanju broja prijavljenih maloljetnih počinilaca krivičnih dijela koji su dobiveni iz službenih podataka za Federaciju BiH, može se

${ }^{1}$ Islamski pedagoški fakultet u Bihaću 
konstatovati da svaki osmi izvršilac krivičnog djela ima ispod 18 godina. U Tuzlanskom kantonu, na inicijativu Udruženja Vijeća škola i roditelja, u 2006. godini sprovedeno je istraživanje sa učenicima V, VI i VII razreda osnovnih škola. ${ }^{2}$ Rezultati pokazuju da je oko $65 \%$ djece koja su učestvovala $u$ istraživanju bilo izloženo nasilju od strane druge djece. Prema službenim podacima Kantonalnog tužilaštva Zeničko-dobojskog kantona, od 2005. godine do 2007. godine, evidentirano je 752 prekršaja, od kojih je samo 180 na području Općine Zenica. ${ }^{3}$ Iako nam se čini da je brojka od 180 mala, ne treba zanemariti podatak da su u istoj godini, od strane Centra za socijalni rad Zenica, evidentirana 203 maloljetnika koja su bila na granici sukoba sa zakonom, te da je otvoreno 119 novih predmeta od čega je novoevidentiranih prijestupnika 72 , a recidivista $47 .{ }^{4}$ Naime, zabrinjava podatak koji se odnosi na karakter krivičnog djela, dob počinitelja i trend koji uključuje sve veći broj udruživanja maloljetnika u manje ili više organizirane grupe, ne samo sa svojim vršnjacima nego i s punoljetnim počiniteljima krivičnih djela. ${ }^{5}$ Prema podacima Kantonalnog tužilaštva i sudova s područja Zeničkodobojskog kantona, najviše krivičnih djela koja počine maloljetnici odnosi se na krađe, ali nisu zanemarljivi ni prekršaji počinjeni protiv života, tijela, spolnog integriteta $i$ drugih djela poput: ubistva, čedomorstva, teških tjelesnih povreda, učestvovanja u tuči i teškim krađama, razbojništva, šumske krađe, nedozvoljeno držanje oružja, oštećenja tuđih stvari, posjedovanja i uživanja opojnih droga, spolnog odnosa maloljetnika, ugrožavanja sigurnosti, lažnog prijavljivanja, neovlaštenog snimanja, povrede mira pokojnika i druga nasilnička ponašanja gdje je recidivizam više nego evidentan. Ispitivanja sive brojke kriminaliteta pokazuju da je broj maloljetnih počinilaca krivičnih djela znatno veći nego što to proizlazi iz statističkih podataka službe socijalne zaštite, policije, javnih tužilaštava ili sudova. Ovo nam govori samo da trebamo biti oprezniji u donošenju zaključaka o maloljetničkom prijestupništvu na temelju službenih podataka. Stanje maloljetničkog

\footnotetext{
${ }^{2}$ Udruženje Vijeća škola i roditelja (2006). Prevencija i intervencija u smanjenju nasilja nad djecom i omladinom. Tuzla.

3 Iz istih izvora saznajemo da je u Zeničko -dobojskom kantonu u 2006 godini evidentirano 201 krivično djelo međutim u 2007 godini došlo je do smanjenja maloljetnih počinilaca krivičnih djela na 193.

${ }^{4}$ Naša riječ, 19.02.2008, ( str. br.5)

5 Još zanimljiviji je podatak da se sve više snižava starosna dob izvršilaca, da među djecom uzrasta od 14 -16 godina ima i onih sa više stotina krivičnih djela u svojim dosjeima.
} 
prijestupništva, posmatrano kroz djelokrug organa unutrašnjih poslova, nikada nije bilo teže. Jedan od razloga jeste i nedostatak kaznenopopravnih zavoda zatvorenog tipa za maloljetnike. Naime, česta praksa je da sud izrekne neku od kaznenih mjera za počinioce koju oni nemaju gdje izdržavati. Zbog navedene situacije, prognoze stručnjaka koji se bave ovom problematikom govore da će Bosna i Hercegovina za deset godina imati više od 1.000 visokoeduciranih kriminalaca koji su sada u fazi regrutacije. Prethodno navedeno, samo je jedan od pokazatelja kako delikventno ponašanje u najranijoj dobi uveliko doprinosi kriminalnom povratu maloljetnih počinitelja, kao i daljnjem nastavku kriminalne karijere. ${ }^{6}$ Iako ne postoje zvanični podaci o broju maloljetnika koji su u riziku da ispolje neke od oblika antisocijalnog, devijantnog i prijestupničkog ponašanja, navest ćemo i podatak da je u osnovnim školama u $\mathrm{BiH}$ oko $20 \%$ djece evidentirano s posebnim odgojnim i obrazovnim potrebama. ${ }^{7}$ Nastavnici ih uglavnom opisuju kao učenike koji ometaju obrazovni proces, koji bježe sa časova, agresivno se ponašaju ili su pasivni i ne učestvuju u nastavi. Ovi učenici često izbjegavaju učešće u aktivnostima i dolaze u situaciju da obnavljaju godinu. Za njih možemo reći da su u riziku da usvoje društveno neprihvatljive oblike ponašanja i dođu u sukob sa zakonom. U školi se ovakva djeca tretiraju tek na kraju razvoja devijantnog ponašanja, tj. kada su već stečene određene navike i zabilježeni brojni prekršaji. ${ }^{8}$ Iako postoji čitav niz oboljenja koja su udružena sa poremećajem u ponašanju, u starijoj adolescentnoj dobi prisutna je i zloupotreba psihoaktivnih supstanci. Epidemiološka istraživanja na području ZE-DO kantona ukazuju da adolescenti s ovim poremećajem najprije posežu za tzv. legalnim drogama (nikotin i alkohol), a potom prelaze na marihuanu, nerijetko i na heroin. Istraživanja pokazuju da su krivična djela

\footnotetext{
${ }^{6}$ Djeca mlađa od 14 godina ne mogu kazneno odgovarati niti se protiv njih podnosi kaznena prijava. Za njih su odgovorni roditelji. Njihovo se ponašanje ispravlja isključivo odgojnim metodama i pedagoškim postupcima u obitelji, školi i dječjim domovima.

${ }^{7}$ Najčešće korišćena klasifikacija poremećaja u ponašanju djece i adolescenata je ona iz Dijagnostičkog i statističkog priručnika za duševne poremećaje (DSM-IV, 1998). Ta klasifikacija poremećaje svrstava u slijedeće kategorije: poremećaji učenja, poremećaji motoričkih vještina, pervarzivni razvojni poremećaji, deficit pažnje i poremećaji s nasilničkim ponašanjem, poremećaji uzimanja hrane i hranjenja u dojenačkom dobu ili ranom djetinjstvu, tikovi, poremećaji komuniciranja, poremećaji eliminacije, te drugi poremećaji.

8 Centar za socijani rad u Zenici je u 2007. godini zabilježio 371 slučaj odgojnozapuštene djece, a 820 djece čiji je razvoj ometen porodičnim prilikama.
} 
maloljetnika usko povezana sa rasturanjem i konzumiranjem opojnih droga. U Bosni i Hercegovini veoma malo je rađeno na pronalaženju uzroka koji dovode do ovakvih oblika ponašanja kod djece i mladih. Dosadašnja istraživanja pokazuju da su to faktori vezani za ličnost $i$ porodicu maloljetnika, socijalni uslovi u kojima on živi, pritisak vršnjaka, utjecaj medija i mnoštvo drugih elemenata. Upozorenja stručnjaka iz različitih naučnih oblasti ukazuju na to da se moraju hitno poduzeti mjere prevencije koje imperativno nameću potrebu sveobuhvatne akcije i većeg nadzora nad maloljetnom djecom. Naime, proučavanje faktora rizika za razvoj tzv. hroničnog delikventnog ponašanja, pokazalo je da je upravo delikvencija u dječijoj dobi jedan od važnijih pokazatelja kasnijeg kriminalnog povrata (Ajduković, M., 1994: 6). Iako je još 2006. godine usvojena Strategija prevencije maloljetničkog prijestupništva, u nekim kantonima se ne primjenjuje, a u nekim je tek započeta primjena, kao što je slučaj sa Zeničko-dobojskim kantonom. U provođenju mjera suzbijanja maloljetničkog prijestupništva neophodno je izlaz tražiti u adekvatnom sprovođenju programa prevencije koji ima multidisciplinarni pristup u svojoj sprovedbi. Naime, neophodna je mobilizacija svih društvenih faktora (ekonomskih, socijalnih, obrazovnih, odgojnih, kulturnih, zdravstvenih i dr.), kako bi se maloljetnicima pružili što bolji uslovi za pravilan razvoj ili im se pomoglo da postignu svoju potpunu resocijalizaciju.

\section{Cilj istraživanja}

Istraživanje ima za cilj da utvrdi faktičko stanje poremećaja ponašanja kod učenika ranog adolescentnog uzrasta, dodatno analizira, sistematizuje i izvrši komparaciju uzročno-posljedičnih faktora njegovog nastanka. Specifični cilj rada je usmjeren ka iznalaženju prirode povezanosti rizičnih faktora sa poremećajem u ponašanju učenika, kako bi se poduzele adekvatne mjere u pronalaženju strategija koje bi dale trajne i učinkovite rezultate u prevalenciji i korekciji poremećaja ponašanja. Istraživanjem je obuhvaćeno 1.080 učenika iz osam osnovnih i osam srednjih škola uzrasta od 13 do18 godina na području općine Zenica. U ovom istraživanju zanima nas u kojoj mjeri učenici osnovnih i srednjih škola ispoljavaju:

- nesocijalizovani poremećaj ponašanja u kome je prisutno trajno antisocijalno ponašanje sa značajno rasprostranjenim oštećenjem odnosa s drugom djecom (nasilno, osvetoljubivo i agresivno 
ponašanje, nebriga, suprotstavljanje, druženje s agresivnim vršnjacima, ometanje školskih aktivnosti, uživanje u nasilju i ekstremna povučenost),

- socijalizovani poremećaj ponašanja koji se manifestuje stalnim antisocijalnim ponašanjem pojedinca koji je uglavnom dobro integriran u grupu vršnjaka (laž, skitnja, ovisnost, promiskuitet),

- nesocijalizovan poremećaj ponašanja koji se manifestuje u tihoj agresivnosti izraženoj kroz: izrugivanje, ismijavanje, omalovažavanje, vrijeđanje i širenje loših glasina, ignorisanje i nagovaranje, izazivanje i upućivanje prijetećih pogleda, zastrašivanje i slanje uznemirujućih i okrutnih prijetnji, nedozvoljeno snimanje i fotografisanje itd.,

- društveno neprihvatljivo ponašanje prijestupničkog tipa koje se manifestuje kroz saučesništvo u napadu, krađu ili uništavanje, korištenje hladnog i vatrenog oružja.

Da bismo osvijetlili ovaj problem, ispitat ćemo frekventnost fenomena društveno neprihvatljivog ponašanja među učenicima, potom ćemo ispitati najčešće vidove poremećaja ponašanja i od strane koga su oni počinjeni - da li se radi o vršnjacima, mlađim ili starijim učenicima i kojeg su spola. Imajući u vidu potrebu ranog uočavanja i tretiranja poremećaja u ponašanju kod učenika osnovnih i srednjih škola, predmet istraživanja je obuhvatio i pitanja koja se tiču ispitivanja povezanosti društveno neprihvatljivog ponašanja sa porodičnim, sredinskim i školskim faktorom. To svakako uključuje uočavanje izvjesnih zakonitosti o spomenutim faktorima koji su presudni za razvoj atipičnih formi ponašanja i načina njihovog djelovanja. Dobiveni rezultati mogu dati skromni doprinos u iznalaženju adekvatnih odgojnih preporuka, programa pa čak i intervencija rizičnog ponašanja kod djece i mladih.

\section{Hipoteze}

Polazeći od predmeta istraživanja, cilja i definiranih zadataka, u ovom radu se krenulo od glavne hipoteze koja pretpostavlja da kod učenika osnovnih i srednjih škola postoji statistički signifikantan procent društveno neprihvatljivog ponašanja koje nalazi svoje mjesto $u$ repertoaru nesocijalizovanog poremećaja ponašanja, trajnog antisocijalnog ponašanja, tihe agresivnosti i prijestupničkog ponašanja, 
koje zahtijeva potrebnu intervenciju od strane stručnih lica. Iz glavne hipoteze proizlazi šest razrađujućih podhipoteza, a to su:

- prva podhipoteza pretpostavlja da će se sa povećanjem starosne granice učenika povećati i pojavnost društveno neprihvatljivog ponašanja koje zahtijeva potrebnu intervenciju od strane stručnih lica,

- druga podhipoteza pretpostavlja se da je društveno neprihvatljivo ponašanje više zastupljeno kod muških nego kod ženskih ispitanika,

- treća podhipoteza pretpostavlja da je društveno neprihvatljivo ponašanje učenika pretežno urbani fenomen,

- četvrta podhipoteza pretpostavlja da izvanporodični faktori kao što su: zaposlenost roditelja, obrazovanje roditelja, materijalni status, tip i veličina porodice, utječu na društveno neprihvatljivo ponašanje učenika,

- peta podhipoteza pretpostavlja da unutarporodični faktori kao što su: neadekvatan odgojni roditeljski stil, odsustvo kontrole roditelja, smanjen obim i kvaliteta komunikacije s djetetom, utječu na društveno neprihvatljivo ponašanje učenika,

- šesta podhipoteza pretpostavlja da pretrpljeno nasilje ima za posljedicu ispoljavanje društveno neprihvatljivih oblika ponašanja kod učenika.

\section{Određivanje veličine uzorka i metode}

Ispitivanjem je bilo obuhvaćeno 1.352 učenika od kojih je bilo 607 muških i 745 ženskih ispitanika. Kako bismo osigurali reprezentativnost i homogenost uzorka kao i pouzdanost u procesu izvođenja zaključaka, odlučili smo se za slijedeću stratifikaciju:

- rana i srednja adolescencija starosti od 13 do 15 godina (540 učenika) $-49.9 \%$,

- stariji adolescenti u dobi od 16 do 18 godina (540 učenika) $50.1 \%$.

Prosječna dob učenika je 15,5 godina. Njihova dobna starost je u rasponu od 13 do 18 godina. Imajući u vidu da se radi o maloljetnim osobama, jedan dio istraživačkih pitanja je urađen uz pristanak roditelja 
ili staratelja. Što se tiče kriterija koji tretira uzorak škole, istraživanje je obuhvatilo ukupno 15 škola, od kojih je osam osnovnih i sedam srednjih škola. Dizajn istraživanja predstavlja kompilaciju kvantitativnog i kvalitativnog istraživanja. Kvantitativno istraživanje je obuhvatilo statističku obradu podataka iz upitnika samoprocjene ispitanika, dok je komponenta kvalitativnog dijela obuhvaćena kroz analizu prikupljenih podataka iz studija slučaja, fokus-grupa i intervjua s djecom koju su nastavnici, pedagozi, socijalni radnici i odgajatelji prepoznali kao djecu koja ispoljavaju poremećaje u ponašanju.

\section{Analiza i interpretacija rezultata poremećaja ponašanja}

Izučavanje devijantnog ponašanja djece i mladih ima ogroman praktični značaj, jer se time omogućava efikasnije suzbijanje društveno neprihvatljivih pojava kod najmladih starosnih kategorija. U ovom istraživanju nismo se oslanjali samo na postojeću literaturu i saznanja drugih o djeci, nego smo ovaj rad posvetili i konkretnim situacijama i iskustvima djece kada je riječ o društveno neprihvatljivom ponašanju. Ovo istraživanje je rađeno na velikom i reprezentativnom uzorku učenika osnovnih i srednjih škola na području $\mathrm{BiH}$ (1.080). Podaci dobiveni upitnikom ne omogućavaju donošenje iznijansiranih zaključaka. Međutim, ono što smo dobili ovim istraživanjem smatramo relevantnim i pouzdanim pokazateljem stanja neprilagođenih oblika ponašanja kod učenika. Polazeći od utvrđenih rezultata, faktorskom analizom je omogućeno prepoznavanje često iskazanih tipova ponašanja učenika koja se odnose na psihosocijalno profiliranje karakterističnih skupina adolescenata koje smo razvrstali u četiri grupe. Utvrđena je statistička značajnost i stepen povezanosti sklonosti sva četiri tipa ponašanja u odnosu na spol, uzrast i socijalnu teritoriju, dok je pojavljivanje ostalih sociodemografskih obilježja kao značajnih izvora razlika, ovisilo o analiziranom tipu ponašanja. Dobiveni rezultati dovoljno svjedoče o velikoj toleranciji koje društvo ima prema ponašanju maloljetnih osoba. Čak, i kada bi dobiveni rezultati bili dvostruko manji, pojedini vidovi ponašanja bi i dalje bili alarmantni.

Rezultati prve kategorije društveno neprihvatljivog ponašanja u kome je prisutan nesocijalizovani poremećaj ponašanja maloljetnika pokazuju da je kod učenika osnovnih i srednjih škola u prosjeku 28.8\% prisutan ovaj vid ponašanja. To se može vidjeti u tabeli br. 1. Analizom deskriptivnih podataka pojedinačnih varijabli utvrđeno je konstantno 
suprotstavljanje roditeljima u 39.1\% slučajeva i da ne postoji povezanost u ponašanju suprotstavljanja roditeljima kod učenika osnovnih i srednjih škola $(r=-0,042 \mathrm{p}>0.01)$. Dječaci se više suprotstavljaju roditeljima $i$ to u $22.59 \%$ slučajeva, za razliku od djevojčica koje se suprotstavljaju roditeljima u $16.48 \%$ slučajeva.

Tabela br. 1: Prikaz frekvencije rezultata uəroka suprotstavljanja roditeljima

\begin{tabular}{|c|c|c|c|c|c|}
\hline Uzroci & \multicolumn{5}{|c|}{ Konstantno se suprotstavljam roditeljima } \\
\hline Suprotstavljanje roditeljima & da & $\mathrm{Ne}$ & da i ne & nikada & Total \\
\hline pametovanje roditelja & 66 & 147 & 45 & 3 & 261 \\
\hline $\begin{array}{l}\text { ne suprotstavljam se } \\
\text { roditeljima }\end{array}$ & 65 & 226 & 38 & 15 & 344 \\
\hline nefer odnos prema meni & 39 & 100 & 27 & 0 & 166 \\
\hline kada mi uskrate nešto & 35 & 75 & 13 & 0 & 123 \\
\hline $\begin{array}{l}\text { kad me ponižavaju i } \\
\text { podcjenjuju }\end{array}$ & 21 & 74 & 16 & 0 & 111 \\
\hline kad me prisiljavaju na nešto & 7 & 14 & 1 & 0 & 22 \\
\hline $\begin{array}{l}\text { poštujem roditelje i ne ljutim } \\
\text { se }\end{array}$ & 5 & 2 & 5 & 0 & 12 \\
\hline fizičko maltretiranje & 3 & 8 & 7 & 1 & 19 \\
\hline Nerazumijevanje & 2 & 5 & 2 & 1 & 10 \\
\hline kada me optuže bez razloga & 0 & 1 & 3 & 0 & 4 \\
\hline kada diraju moje stvari & 1 & 3 & 0 & 0 & 4 \\
\hline psovanje bez razloga & 1 & 2 & 0 & 0 & 3 \\
\hline kad mi ne vjeruju & 0 & 1 & 0 & 0 & 1 \\
\hline Total & $\begin{array}{c}245 \\
(23.51 \%)\end{array}$ & $\begin{array}{c}658 \\
(60.92 \%)\end{array}$ & $\begin{array}{c}157 \\
(14.53 \%)\end{array}$ & $\begin{array}{c}20 \\
(1.85 \%)\end{array}$ & $\begin{array}{c}1080 \\
(100 \%)\end{array}$ \\
\hline
\end{tabular}

U okviru prve kategorije poremećaja, utvrđeno je da postoji povezanost između gledanja filmova i igranja igrica koji su puni nasilja sa agresivnim ponašanjem učenika, te je ona statistički značajna na oba nivoa značajnosti $(\mathrm{r}=0,209 ; \mathrm{p}<0,01)$. Također, utvrđeno je da postoji povezanost igranja kompjuterskih igrica koje obiluju nasiljem sa ponašanjem učenika koje se manifestuje povlačenjem u sebe. Učenici ispoljavaju agresivno ponašanje, kako prema odraslima, tako i prema maloljetnim osobama i to u $14,9 \%$ slučajeva. Nije utvrđeno da postoji povezanost tipa porodice i druženja njihove djece sa vršnjacima koji imaju agresivno i nasilno ponašanje $(r=0.00, \mathrm{p}>0.01)$. Kod adolescenata je izražena burna reakcija koja se manifestuje nasilnim i osvetoljubivim ponašanjem u $31,9 \%$ slučajeva. Nije utvrđena povezanost 
društveno neprihvatljivog ponašanja koje se manifestuje u nasilnom ponašanju i varijable koje nas informišu o statusu bračnosti roditelja maloljetnika $(\mathrm{r}=0,00, \mathrm{p}>.0,01)$. U tabeli br. 2 prikazana je prisutnost devet rizičnih ponašanja kod učenika osnovnih i srednjih škola koja mogu prerasti u društveno neprihvatljivo ponašanje ukoliko se ne poduzmu pravovremene interventne mjere koje imaju za cilj suzbijanje ovakvih vidova ponašanja.

Tabela br. 2: Prikaz statistickih pokazatelja varijabli nesocijalizovanog poremé́aja ponašanja

\begin{tabular}{|l|c|c|c|c|c|c|c|}
\hline N=1080 & Da $\%$ & Ne $\%$ & Mean & Std.dev & Chi-Squar & df & p. Sig \\
\hline $\begin{array}{l}\text { Imam lošu pažnju i ne mogu } \\
\text { se koncentrisati nikada }\end{array}$ & 26.2 & 73.8 & 1.7380 & .43995 & 244.626 & 1 & .000 \\
\hline $\begin{array}{l}\text { Na kritike i zadirkivanje } \\
\text { reagujem nasilno i } \\
\text { osvetoljubivo }\end{array}$ & 31.9 & 68.1 & 1.6806 & .46648 & 140.833 & 1 & .000 \\
\hline $\begin{array}{l}\text { Uživam u agresivnom } \\
\text { ponašanju iako za to nemam } \\
\text { razloga }\end{array}$ & 14.9 & 85.1 & 1.8509 & .35633 & 532.004 & 1 & .000 \\
\hline $\begin{array}{l}\text { Ne brinem za osjećanja i } \\
\text { prava drugih }\end{array}$ & 15.8 & 84.2 & 1.8417 & .36522 & 504.300 & 1 & .000 \\
\hline $\begin{array}{l}\text { Konstantno se } \\
\text { suprotstavljam odraslima i } \\
\text { roditeljima }\end{array}$ & 39.1 & 60.9 & 1.6093 & .48814 & 51.570 & 1 & .000 \\
\hline $\begin{array}{l}\text { Imam prijatelje koji su } \\
\text { agresivni i neposlušni }\end{array}$ & 45.0 & 55.0 & 1.5500 & .49772 & 10.800 & 1 & .001 \\
\hline $\begin{array}{l}\text { Često ometam školske } \\
\text { aktivnosti bez ikakvog } \\
\text { povoda }\end{array}$ & 19.8 & 80.2 & 1.8019 & .39879 & 393.615 & 1 & .000 \\
\hline $\begin{array}{l}\text { Uživam u igricama i } \\
\text { filmovima koji su puni nasilja }\end{array}$ & 43,5 & 56.5 & 1.5648 & .49601 & 18.148 & 1 & .000 \\
\hline $\begin{array}{l}\text { Povučem se i ne želim da } \\
\text { komuniciram s bilo kim }\end{array}$ & 23.0 & 77.0 & 1.7704 & .42079 & 315.793 & 1 & .000 \\
\hline
\end{tabular}

Prema izjavama učenika, najčešće je prisutno druženje učenika sa maloljetnicima koji ispoljavaju agresivno ponašanje (45\%) i uživanje u nasilnim medijima (43.5\%). Uočljivo je prisustvo i agresivnog ponašanja, konstantno suprotstavljanje roditeljima i poremećaj pažnje na nastavi što se može vidjeti iz tabele br. 2. Hi-kvadrat test je statistički značajan na nivou od $0.001 \%$ i govori nam da su u populaciji adolescenata zastupljena ponašanja iz tabele br. 2 . 
U drugoj kategoriji nesocijalizovanog poremećaja ponašanja prisutno je 30,9\% trajnih antisocijalnih ponašanja koja se manifestuju u različitim vidovima koji su prikazani u tabeli broj 3 .

Tabela br. 3: Prikaz, statističkih pokazatelja varijabli nesocijalizovanog poreméaja ponašanja

\begin{tabular}{|l|c|c|c|c|c|c|c|c|}
\hline $\mathrm{N}=1080$ & $\mathrm{Da}$ & Ponekad & $\mathrm{Ne}$ & Mean & Std. dev & Chi-Squar & $\mathrm{df}$ & $\mathrm{p}$. Sig \\
\hline Lažem & 40.4 & 1.2 & 58.4 & 2.1806 & .97788 & 554.517 & 2 & .000 \\
\hline bježim sa nastave & 43.0 & 3.3 & 53.7 & 2.1074 & .97776 & 456.089 & 2 & .000 \\
\hline bježim od kuće & 6.1 & 3.7 & 90.2 & 2.8407 & .50632 & 1571.756 & 2 & .000 \\
\hline koristim cigarete & 30.6 & 1.3 & 68.1 & 2.3741 & .92081 & 725.506 & 2 & .000 \\
\hline koristim alkohol & 40.6 & 1.2 & 58.2 & 2.1769 & .97856 & 552.372 & 2 & .000 \\
\hline koristim droge & 5.8 & 0.9 & 93.2 & 2.8741 & .47639 & 1748.106 & 2 & .000 \\
\hline kockam se & 27.4 & 1.4 & 71.2 & 2.4380 & .89165 & 806.672 & 2 & .000 \\
\hline $\begin{array}{l}\text { gledam porno } \\
\text { filmove }\end{array}$ & 45.6 & 1.6 & 52.9 & 2.0731 & .98986 & 498.872 & 2 & .000 \\
\hline $\begin{array}{l}\text { intimni odnosi sa } \\
\text { suprotnim spolom }\end{array}$ & 25.5 & 25.5 & 49.1 & 2.2361 & .83082 & 120.417 & 2 & .000 \\
\hline $\begin{array}{l}\text { intimni odnosi sa } \\
\text { istim spolom }\end{array}$ & $3.9 \%$ & $0.9 \%$ & $96.1 \%$ & 2.9315 & .35099 & 1916.022 & 2 & .000 \\
\hline
\end{tabular}

Korišćenje laži je prisutno u procentu od $41,6 \%$, te je utvrđeno da učenici srednjih škola dva puta više lažu od osnovaca. Utvrđeno je i da ne postoji statistički značajna razlika u odgovorima dječaka i djevojčica kada je riječ o lažima. Također, utvrđena je povezanost sredine stanovanja maloljetnika sa korišćenjem laži $(\mathrm{r}=0,078, \mathrm{p}<0,01)$, gdje su učenici iz ruralnih sredina manje skloniji laži od učenika iz urbanih sredina. Rezultati pokazuju da se moralni sudovi u izvjesnoj mjeri razlikuju u slučaju kada učenici znaju da će oni biti saopćeni odraslima ili vršnjacima i u slučaju kada su oni anonimni. Bježanje sa nastave prisutno je u 46.3\% slučajeva. Učenici srednjih škola skoro dva puta više bježe sa časova nego učenici osnovnih škola. Dječaci dva puta više bježe sa nastave u odnosu na djevojčice. Tri najfrekventnija izgovora koja učenici navode za bježanje sa nastave su: dosadna i nezanimljiva nastava (30.5\%), nerealno ocjenjivanje (27.3\%), izbjegavanje loše ocjene, tj. nespremnost za nastavu (19.6\%). Zabilježili smo i bježanje od kuće u 9.8 $\%$ slučajeva. Utvrđena je povezanost bježanja od kuće sa spolom ( $\mathrm{r}=$ 0,091; $\mathrm{p}<0,01)$. Naime, dječaci više bježe od kuće nego djevojčice. Nije utvrđena povezanost bježanja od kuće i socijalne teritorije $(r=-0,023, p$ 
$>0,01)$. Ne postoji statistička značajnost u pogledu bježanja starijih i mlađih maloljetnika $(\mathrm{r}=-0,011, \mathrm{p}>0,01)$. Utvrđena je povezanosti roditeljskih stilova i bježanja maloljetnika od kuće. Naime, indolentan, autoritativan i permisivan odgojni stil negativno utječe na bježanje maloljetnika od kuće. S druge strane, autoritativni tip roditeljstva prevenira bježanje djece od kuće. Kada je u pitanju ovisnost, utvrđeno je da svaki treći maloljetnik konzumira duhan. Učenici osnovnih škola koriste dva puta manje duhan u odnosu na srednjoškolce. Dječaci više konzumiraju cigarete od djevojčica. Razlozi za konzumiranje duhana su prikazani u tabeli br. 4, a dobivena korelacija korištenja duhana i socijalne teritorije ne ukazuje na njihovu povezanost $(\mathrm{r}=0,048, \mathrm{p}>0,01)$.

Tab. br. 4: Učeničko videnje rąloga korištenja cigareta

\begin{tabular}{|l|c|c|c|c|c|c|c|c|c|c|c|c|c|c|c|c|}
\hline UZROCI & A & B & C & D & E & F & G & I & J & K & L & M & N & O & P & Tot \\
\hline često & 22 & 10 & 3 & 12 & 3 & 3 & 8 & 1 & 3 & 1 & 0 & 2 & 5 & 3 & 2 & 98 \\
\hline ponekad & 32 & 4 & 3 & 9 & 6 & 4 & 9 & 1 & 1 & 0 & 1 & 3 & 2 & 0 & 4 & 94 \\
\hline rijetko & 19 & 6 & 0 & 2 & 2 & 1 & 6 & 1 & 0 & 0 & 0 & 3 & 1 & 0 & 2 & 50 \\
\hline jednom & 32 & 5 & 6 & 8 & 5 & 5 & 7 & 0 & 0 & 2 & 0 & 0 & 2 & 0 & 5 & 89 \\
\hline planiram & 4 & 2 & 0 & 0 & 0 & 0 & 2 & 2 & 2 & 0 & 0 & 0 & 2 & 2 & 1 & 14 \\
\hline Total 1 & 109 & 27 & 12 & 31 & 16 & 13 & 32 & 5 & 6 & 3 & 1 & 8 & 12 & 5 & 14 & 294 \\
\hline Ne konz. & 140 & 20 & 32 & 43 & 24 & 25 & 41 & 12 & 13 & 8 & 6 & 13 & 28 & 5 & 14 & 424 \\
\hline Bez odg. & 0 & 0 & 0 & 0 & 0 & 0 & 0 & 0 & 0 & 0 & 0 & 0 & 0 & 0 & 0 & 311 \\
\hline Total 2 & 249 & 47 & 44 & 74 & 40 & 38 & 73 & 17 & 19 & 11 & 7 & 21 & 40 & 10 & 28 & 1080 \\
\hline
\end{tabular}

LEGENDA: $A$ - i₹ radoznalosti, $B$ - da se osjeća va:̌nim, $C$ - neznanje, $D$ - dosada, E - nagovor vršnjaka, F - ̌̌elja da bude kao drugi, G - ljubav, I strah od kazne, $J$ - obaveze, $K$ - neslaganje s roditeljima, $L$ - neslaganje sa clanovima porodice, $M$ - řelja za samostalnošcu, $N$ - interes, $O$ - konfliket s prijateljima, $P$ stres;

Adolescenti konzumiranju alkohol u procentu od $41.8 \%$. Dječaci dva puta više koriste alkohol u odnosu na djevojčice. Srednjoškolci dva puta više koriste alkohol u odnosu na maloljetnike iz osnovnih škola. $\mathrm{Ne}$ postoji povezanost između korištenja alkohola i socijalne sredine iz koje dolaze maloljetnici $(\mathrm{r}=0,046, \mathrm{p}>0,01)$. 
Grafikon br. 1: koristenje alkohola (usrast)

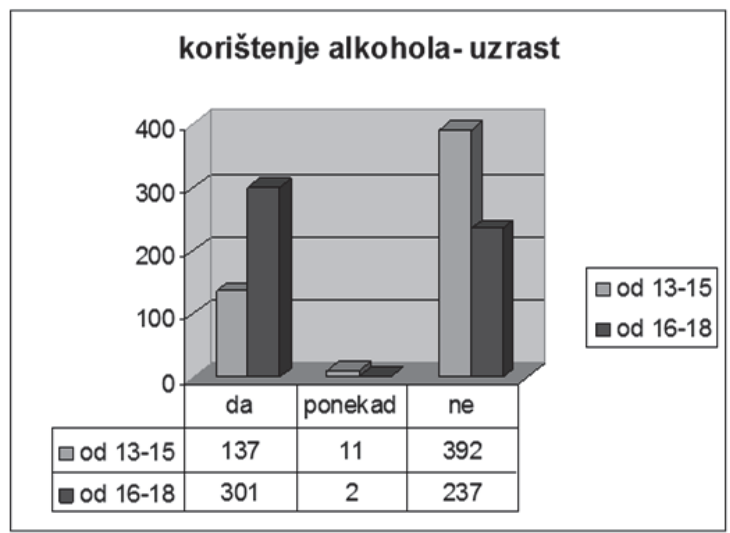

Grafikon br.2: koristenje alkohola ( spol)

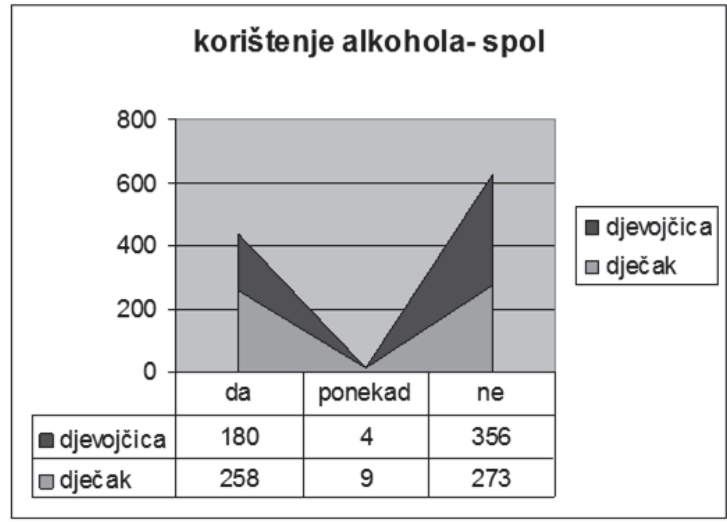

Kada su u pitanju droge, 6.75\% maloljetnika je jednom ili više puta probalo drogu. Ne postoji statistički značajna razlika u pogledu korištenja droge između učenika osnovnih i učenika srednjih škola. Također, ne postoji statistički značajna razlika u korištenju droga kod dječaka i djevojčica. Istraživanje nije pokazalo statistički značajnu razliku u pogledu korištenja droga između maloljetnika koji žive u urbanim i ruralnim sredinama $(\mathrm{r}=0.005, \mathrm{p}>0.01)$. $\mathrm{U}$ ovoj kategoriji ispitana je $\mathrm{i}$ ovisnost o kockanju mladih. Pokazalo se da 28.08\% maloljetnika redovno posjećuje kladionice, od čega 5.55\% djevojčica i $23.24 \%$ dječaka redovno kocka. Maloljetnici iz urbanih sredina ne iskazuju značajno veću pojavnost posjećivanja kladionica od maloljetnika iz ruralnih sredina. 
Tabela br. 5: Ućestalost korištenja kladionica $i$ aparata za kockanje kod maloljetnika (kat-raared)

\begin{tabular}{|l|c|c|c|c|c|c|c|}
\hline $\begin{array}{l}\text { KOCKAM SE } \\
\text { ( kladionice, } \\
\text { aparati) }\end{array}$ & VII & VIII & I R & II R & III R & IVR & Total \\
\hline veoma često & 17 & 7 & 7 & 10 & 10 & 10 & 61 \\
\hline ponekad & 40 & 11 & 15 & 30 & 33 & 31 & 160 \\
\hline u posebnim prilikama & 11 & 2 & 5 & 9 & 6 & 8 & 41 \\
\hline samo jednom probao & 5 & 1 & 5 & 4 & 10 & 9 & 34 \\
\hline imam namjeru & 2 & 3 & 0 & 0 & 6 & 4 & 15 \\
\hline ne pomišljam & 222 & 88 & 80 & 125 & 110 & 118 & 743 \\
\hline bez odgovora & 13 & 3 & 3 & 2 & 5 & 0 & 26 \\
\hline Total & $\mathbf{3 1 0}$ & $\mathbf{1 1 5}$ & $\mathbf{1 1 5}$ & $\mathbf{1 8 0}$ & $\mathbf{1 8 0}$ & $\mathbf{1 8 0}$ & $\mathbf{1 0 8 0}$ \\
\hline
\end{tabular}

U varijabli ovisnosti gledanja neprimjerenih sadržaja, utvrđeno je da porno filmove gleda $47.2 \%$ maloljetnika, dok $50 \%$ posjećuje porno stranice na Internetu. Veći interes pokazuju učenici srednjih škola. Oko $38.55 \%$ dječaka gleda porno filmove, za razliku od djevojčica koje to gledaju u $9.07 \%$ slučajeva. Nije utvrđena povezanost socijalne teritorije stanovanja maloljetnika i gledanja porno sadržaja $(r=-0,003, \mathrm{p}>0,01)$.

Grafikon br.3: Gledanje porno filmova - urrast

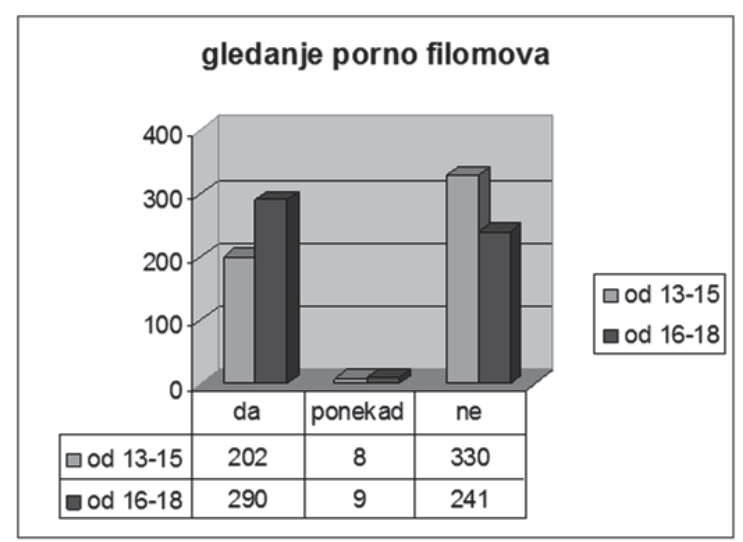


Grafikon br. 4: gledanje porno stranica - uærast

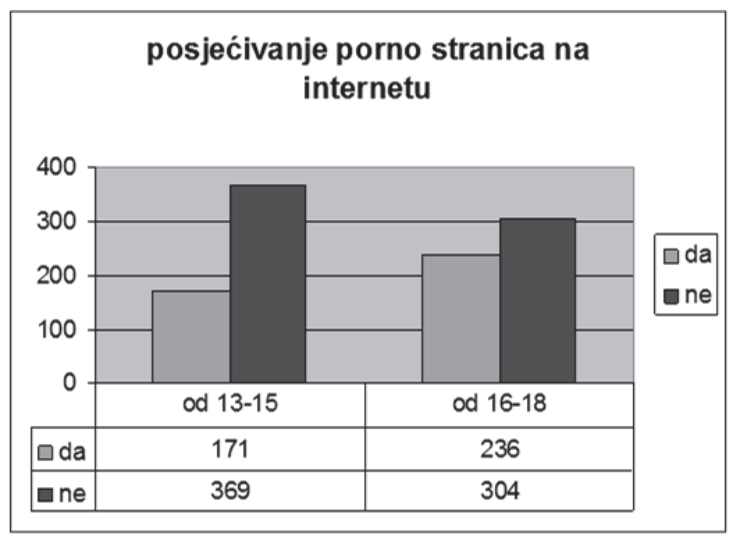

Gledanje pornografskih sadržaja se dovodi u vezu sa ranim stupanjem u intimne odnose. Utvrđeno je da $25.5 \%$ mladih stiču prva seksualna iskustva u prosjeku sa 13.8 godina. Oko 21.25\% dječaka i $4.25 \%$ djevojčica stupa u intimne odnose. Razlike među posmatranim varijablama na uzrastu pokazuju da postoji vrlo slaba korelacija u odnosu na uzrast koja sa povećanjem dobi raste $(\mathrm{r}=-0.124, \mathrm{p}<0,01)$. Utvrđena je povezanost mjesta stanovanja maloljetnika i ulaska maloljetnika u intimne odnose sa suprotnim spolom $(r=0,064 \mathrm{p}<0,01)$. Učenici iz gradskih sredina su skloniji ulasku u intimne odnose od učenika iz ruralnih sredina. Ispitan je i ulazak u rizične seksualne radnje sa istim spolom gdje je 3.8\% maloljetnika imalo ovu vrstu seksualnog iskustva, od čega su 1,20\% djevojčice i 2, 68\% dječaci. Nije utvrđena povezanost socijalne teritorije stanovanja maloljetnika i ulaska u intimne odnose sa istim spolom $(\mathrm{r}=-0,054, \mathrm{p}>0,01)$. 
Grafikon br. 5: Ulazak u intimne odnose kategorija spolnosti

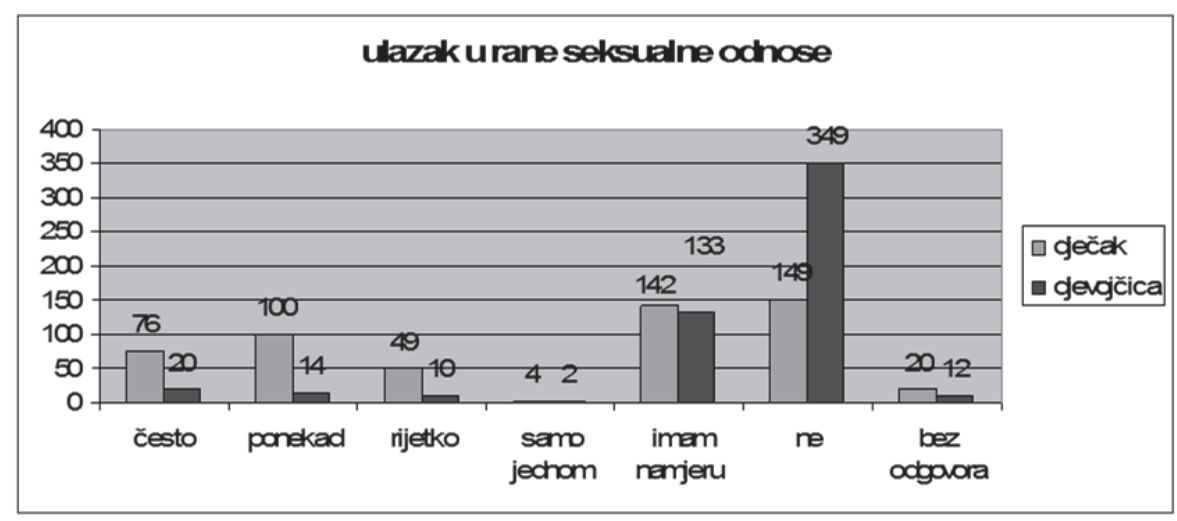

U trećoj kategoriji društveno neprihvatljivog ponašanja koje se manifestuje u tihoj agresivnosti, u prosjeku je zastupljeno 23.93\% slučajeva. Analizom deskriptivnih podataka pojedinačnih varijabli utvrđeno je da u 20.8\% slučajeva maloljetnici ispoljavaju tihu agresivnost koja se manifestuje u ispoljavanju izrugivanja, ismijavanja, omalovažavanja, vrijeđanja i širenja glasina o drugim osobama. Nije utvrđena povezanost ovog tipa ponašanja sa uzrastom maloljetnika ( $\mathrm{r}=$ $0,024, \mathrm{p}>0,01)$. Što se tiče spolnosti, utvrđena je veoma niska korelacija sa ovim vidom ponašanja $(r=0,076, p>0,01)$. Dječaci su ti koji češće koriste ovaj vid ponašanja. Nije utvrđena povezanost u ponašanju maloljetnika iz urbanih i ruralnih sredina $(r=-0,025, \mathrm{p}>0,01)$. Svaki treći maloljetnik, tj. 34.7\% maloljetnika ignoriše osobu i nagovara druge da se ne druže sa njom. Ne postoji povezanost nagovaranja drugih da se ne druže sa kategorijom uzrasta $(\mathrm{r}=-0,007, \mathrm{p}>0,01)$, spolom ispitanika $(\mathrm{r}=0,056, \mathrm{p}>0,01)$ i socijalnom sredinom $(\mathrm{r}=-0,005, \mathrm{p}>0,01)$. Oko $17.07 \%$ učenika izaziva i upućuje prijeteće poglede, stalno zastrašuju i prate osobe. Što se tiče uzrasta, ne postoji povezanost $(r=-0,007, p>$ $0,01)$, kao i u pogledu povezanosti ovog tipa ponašanja i spola ispitanika $(\mathrm{r}=0,29, \mathrm{p}>0,01)$. Nije utvrđena statistička značajnost u pogledu povezanosti ovog vida ponašanja sa socijalnom sredinom stanovanja maloljetnika $(\mathrm{r}=0,091, \mathrm{p}>0,01)$. 
Grafikon br. 6: Prijetnja i zastrasivanje (spol)

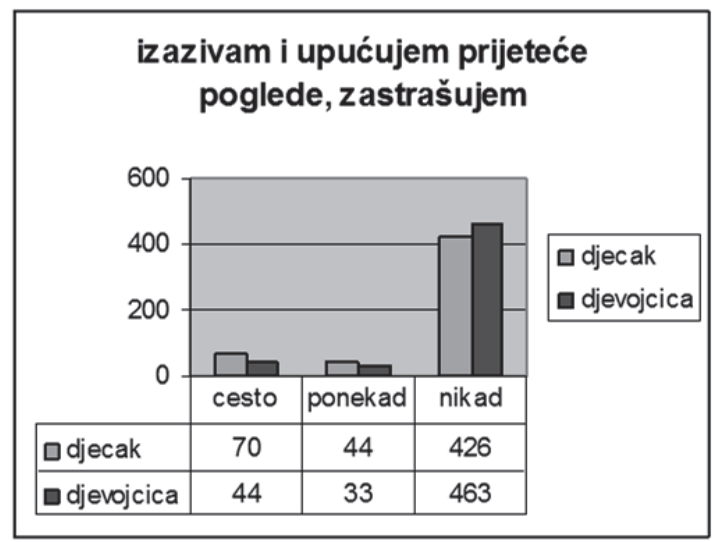

Grafikon br. 7: Prijetnja i zastrašivanje (uৃrast)

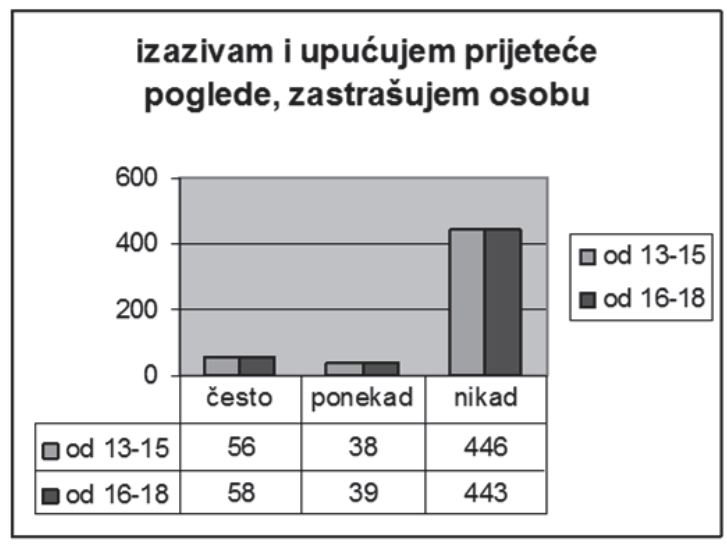

$\mathrm{U}$ istoj kategoriji ispitanih varijabli utvrđeno je da $23.09 \%$ maloljetnika uputi svojim vršnjacima zlobnu i okrutnu prijetnju. Ne postoji statistički značajna povezanost ovog tipa ponašanja i uzrasta maloljetnika $(\mathrm{r}=0.021, \mathrm{p}>0.01)$, ali je utvrđena potpuna povezanost $\mathrm{u}$ odgovorima dječaka i djevojčica $(r=0.156, \mathrm{p}<0.01)$. Ovo ponašanje je prisutnije kod dječaka nego kod djevojčica. Uspoređivanjem odgovora učenika iz ruralnih i urbanih sredina, ustanovilo se da ne postoji povezanost u odgovorima koji se odnose na slanje zlobnih i okrutnih prijetnji ( $\mathrm{r}=-0.027, \mathrm{p}>0.01$ ). Oko $24 \%$ maloljetnika snima ili fotografiše neku osobu bez njenog pristanka, od čega je 5.5\% maloljetnika taj snimak zloupotrijebi. Ne postoji statistička značajnost u pogledu povezanosti ovog tipa ponašanja sa uzrastom $(r=0.44 \mathrm{p}>$ 
0.01). Rezultati su pokazali da postoji potpuna povezanost na varijabli neovlaštenog snimanja osoba sa spolnošću ispitanika $(\mathrm{r}=0.147, \mathrm{p}<$ 0.01). Djevojčice su sklonije ovom tipu ponašanja. Nije utvrđena povezanost $u$ ponašanju maloljetnika koji se bave neovlaštenim snimanjem i fotografisanjem sa socijalnim teritorijem $(\mathrm{r}=0.038, \mathrm{p}<$ $0.01)$.

Tabela br. 7: Prikaz statistickih pokazatelja antisocijalnog ponašanja $i$ tihe agresivnosti

\begin{tabular}{|l|c|c|c|c|c|c|c|c|}
\hline $\mathrm{N}=1080$ & $\begin{array}{c}\mathrm{Da} \\
\%\end{array}$ & $\begin{array}{c}\text { Ponekad } \\
\%\end{array}$ & $\begin{array}{c}\mathrm{Ne} \\
\%\end{array}$ & Mean & $\begin{array}{c}\text { Std. } \\
\text { dev. }\end{array}$ & Chi-Squa & Df & Sig \\
\hline $\begin{array}{l}\text { Izrugiva, ismijava, } \\
\text { omalovažava, vrijeđa i širi } \\
\text { glasine o drugima; }\end{array}$ & 8.2 & 12.6 & 79.2 & 2.7093 & .60940 & 1024.006 & 2 & .000 \\
\hline $\begin{array}{l}\text { Ignoriše osobu i nagovara } \\
\text { druge da se ne druže sa } \\
\text { njom/njim; }\end{array}$ & 19.0 & 15.7 & 65.3 & 2.4630 & .79299 & 497.639 & 2 & .000 \\
\hline $\begin{array}{l}\text { Izaziva i upućuje prijeteće } \\
\text { poglede, stalno zastrašuje } \\
\text { osobu; }\end{array}$ & 10.6 & 7.1 & 82.3 & 2.7176 & .64354 & 1167.906 & 2 & .000 \\
\hline $\begin{array}{l}\text { Šalje uznemirujuće i okrutne } \\
\text { prijetnje; }\end{array}$ & 10.9 & 13.0 & 76.0 & 2.6515 & .66796 & 888.280 & 2 & .000 \\
\hline $\begin{array}{l}\text { Snima i fotografiše osobu } \\
\text { bez njenog znanja; }\end{array}$ & 12.8 & 11.2 & 75.9 & 2.6321 & .69915 & 884.165 & 2 & .000 \\
\hline
\end{tabular}

Rezultati četvrte kategorije društveno neprihvatljivog ponašanja u prijestupništvu pokazuju da je u $18.44 \%$ slučajeva prisutno ovo ponašanje kod učenika osnovnih i srednjih škola. Analizom deskriptivnih podataka pojedinačnih varijabli utvrđeno je da $11.6 \%$ učenika osnovnih i srednjih škola krade. Ne postoji povezanost u ponašanju mlađih i starijih maloljetnika sa krađom $(\mathrm{r}=-0,013, \mathrm{p}>0,01)$. Izvodom iz korelacijske matrice utvrdena je povezanost krađe i odnosa sa spolom (korelacija je signifikantna na nivou $\mathrm{p}<0.01, \mathrm{r}=0.190)$. Dječaci ispoljavaju veći stepen krađe od djevojčica. Što se tiče povezanosti krađe sa socijalnim teritorijem stanovanja maloljetnika, utvrđeno je da ne postoji statistička značajnost $(\mathrm{r}=0.024, \mathrm{p}>0.01)$. 
Grafikon br. 8: Krade (spol)

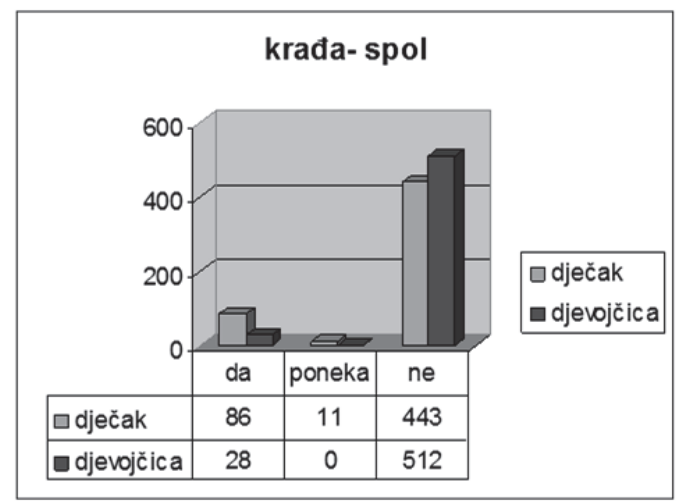

Grafikon br. 9: Krade (urrast)

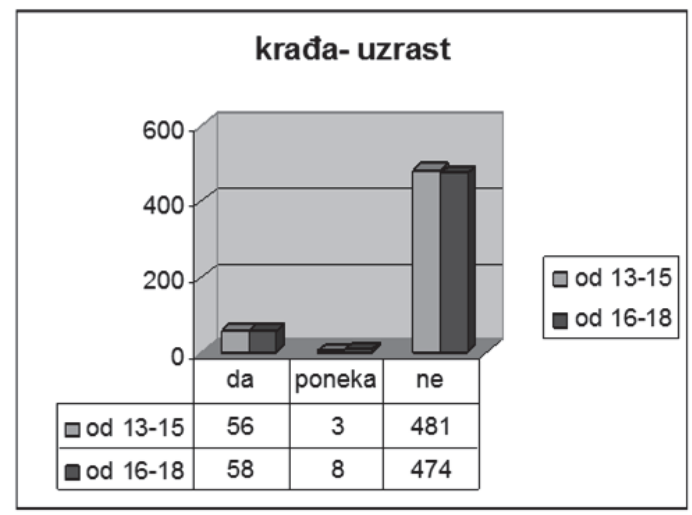

Kod $11.57 \%$ učenika osnovnih i srednjih škola prisutno je ponašanje koje se odnosi na krađu sa uništavanjem imovine. Djevojke dva puta manje sudjeluju u krađi sa uništavanjem imovine. Ne postoji povezanost počinjenog delikta i uzrasta $(\mathrm{r}=0.052, \mathrm{p}>0.01)$. U pogledu mjesta stanovanja učenika koji kradu i uništavaju tuđu imovinu, u našem istraživanju nismo dobili korelaciju statistički značajnu $(\mathrm{r}=-0,003 \mathrm{p}>$ 0.01). To znači da među učenicima koji stanuju u različitim socijalnim sredinama ne postoji razlika u krađi sa uništavanjem imovine. Povezanost materijalnog statusa i delikta krađe sa uništavanje imovine također ne postoji $(\mathrm{r}=-0.017, \mathrm{p}>0.01)$. Oko $22.4 \%$ učenika osnovnih i srednjih škola koristi hladno oružje u konfliktu sa vršnjacima. Postupkom korelacione analize utvrđeno je da ne postoji povezanost u nošenju hladnog oružja i uzrasta. $(r=-0,015, \mathrm{p}>0,01)$. Djevojčice tri puta manje koriste hladno oružje od dječaka. Nije utvrđena povezanost 
nošenja hladnog oružja sa mjestom stanovanja maloljetnika $(\mathrm{r}=-0,017, \mathrm{p}$ $>0,01)$. Približno 12.6\% učenika često nosi vatreno oružje, a 3.7\% povremeno. Korelacionom analizom ustanovljena je statistička značajnost u pogledu nošenja vatrenog oružja i uzrasta $(r=-0.126, p<$ 0.01). Nošenje vatrenog oružja je učestalije kod starijih maloljetnika. Postoji statistička značajnost u pogledu korelacije nošenja vatrenog oružja i spola $(r=0.320, p<0.01)$. Jedna od mjera koje škola koristi $u$ suzbijanju nošenja hladnog oružja je i fizičko kažnjavanje gdje 14.90\% učenika ističe da se u školi često primjenjuje fizičko kažnjavanje učenika, dok je $7.59 \%$ učenika izjavilo da se to radi ponekad. Nije utvrđena povezanost u kažnjavanju muških i ženskih ispitanika $(r=0.08, \mathrm{p}>0.01$ ), premda dječaci koriste više vatreno oružje od djevojčica. Saučesništvo je kod maloljetnika prisutno u $30.27 \%$ slučajeva. Nije utvrđena povezanost saučesnišva i uzrasta $(\mathrm{r}=-0.032, \mathrm{p}>0.01)$. Dobiveni rezultati ukazuju da dječaci sudjeluju u $21.85 \%$ slučajeva u saučesništvu, a djevojčice u $8.42 \%$ slučajeva. Ne postoji statistički značajna razlika između saučesništva u deliktu i mjesta stanovanja. $(r=-0.006, p>0.01)$. Rezultati istraživanja ne pokazuju povezanost nošenja vatrenog oružja i mjesta stanovanja ( $\mathrm{r}=0.012, \mathrm{p}<0.01)$, tj. mjesto stanovanja ne uvjetuje određene neprilagođene oblike ponašanja. Svako četvrto dijete doživjelo je barem jedan od oblika nasilja u školi, porodici i na putu od kuće do škole, pri čemu su 49.79\% djece pasivne žrtve fizičkog nasilja, 7.63\% su žrtve krađe s napadima i $0.80 \%$ su žrtve seksualnog nasilja. Postupkom korelacione analize utvrđena je povezanost pretrpljenog nasilja sa korištenjem hladnog oružja $(\mathrm{r}=-0.064, \mathrm{p}<0.01)$, korištenjem droge $(\mathrm{r}=$ $-0.066, \mathrm{p}<0.01)$, bježanjem sa nastave $(\mathrm{r}=-0.091, \mathrm{p}<0.01)$, ulaskom $\mathrm{u}$ intimne odnose sa suprotnim spolom $(\mathrm{r}=-0.068, \mathrm{p}<0.01)$ i korištenjem alkohola $(\mathrm{r}=-0.120 ; \mathrm{p}<0.01)$.

Tabela br. 8: Prikaz statističkih pokazatelja prijestupničkog ponašanja maloljetnika

\begin{tabular}{|l|c|c|c|c|c|c|c|c|}
\hline $\mathrm{N}=1080$ & $\mathrm{Da} \%$ & $\begin{array}{c}\text { Ponekad } \\
\%\end{array}$ & Ne \% & Mean & $\begin{array}{c}\text { Std. } \\
\text { dev. }\end{array}$ & Chi-Squa & Df & Sig \\
\hline saučesništvo u napadu & 18.5 & 11.8 & 69.7 & 2.5120 & .78791 & 650.939 & 2 & .000 \\
\hline ukradem ili uništim & 7.6 & 4.0 & 88.4 & 2.8083 & .55414 & 1477.217 & 2 & .000 \\
\hline koristim hladno oružje & 15.5 & 6.9 & 77.7 & 2.6222 & .73812 & 968.017 & 2 & .000 \\
\hline kradem & 10.6 & 1.0 & 88.4 & 2.7787 & .61951 & 1245.867 & 2 & .000 \\
\hline nosim vatreno oružje & 12.6 & 3.7 & 83.7 & 2.7111 & .67654 & 1.490 & 2 & .000 \\
\hline
\end{tabular}

S obzirom da je kod učenika osnovnih i srednjih škola u prosjeku ustanovljena prisutnost od $20.51 \%$ društveno neprihvatljivog ponašanja 
koje nalazi svoje mjesto u repertoaru nesocijalizovanog poremećaja ponašanja, trajnog antisocijalnog ponašanja, tihe agresivnosti i ponašanja koje ima elemente maloljetničkog prijestupništva, u tabeli br. 9 prikazani su neki od razloga zbog čega adolescenti ispoljavaju poremećaje ponašanja.

Tabela br. 9: Razlozi ulaska u saučesništvo protiv šivota i tijela

\begin{tabular}{|l|c|c|c|c|}
\hline & \multicolumn{3}{|c|}{ saučesništvo u napadu } \\
\hline Razlozi konflikta & da & ponekad & ne & Total \\
\hline Verbalni konflikti & $42(3.88 \%)$ & $27(2.5 \%)$ & $189(17.5 \%)$ & $258(23.88 \%)$ \\
\hline odbacivanje & $14(1.29 \%)$ & $10(0.92 \%)$ & $82(7.59 \%)$ & $106(9.81 \%)$ \\
\hline fizički konflikti & $22(2.03 \%)$ & $13(1.20 \%)$ & $60(5.55 \%)$ & $95(8.79 \%)$ \\
\hline dosadni su i nerviraju me & $14(1.29 \%)$ & $11(1.01 \%)$ & $36(3.33 \%)$ & $61(5.64 \%)$ \\
\hline nisam u konfliktu & $93(8.61 \%)$ & $46(4.25 \%)$ & $256(23.70 \%)$ & $395(36.57 \%)$ \\
\hline Laž & $5(0.46 \%)$ & $9(0.83 \%)$ & $77(7.12 \%)$ & $91(8.42 \%)$ \\
\hline prisiljavanje & $2(0.18 \%)$ & $2(0.18 \%)$ & $14(1.29 \%)$ & $18(1.66 \%)$ \\
\hline ironičan stav & $4(20.37 \%)$ & $4(20.37 \%)$ & $16(1.48 \%)$ & $24(13.33 \%)$ \\
\hline izazivanje & $3(0.27 \%)$ & $4(20.37 \%)$ & $9(0.83 \%)$ & $16(1.48 \%)$ \\
\hline Osveta & $0(0 \%)$ & $0(0 \%)$ & $4(20.37 \%)$ & $4(20.37 \%)$ \\
\hline ponižavanje i ogovaranje & $0(0 \%)$ & $1(0.092 \%)$ & $6(0.55 \%)$ & $7(0.64 \%)$ \\
\hline $\begin{array}{l}\text { kad uzmu moje stvari i ne } \\
\text { vrate }\end{array}$ & $1(0.092 \%)$ & $0(0 \%)$ & $1(0.092 \%)$ & $2(0.18 \%)$ \\
\hline nepravda & $0(0 \%)$ & $0(0 \%)$ & $3(0.27 \%)$ & $3(0.27 \%)$ \\
\hline Total & $\mathbf{2 0 0 ( 1 8 . 5 1 \% )}$ & $\mathbf{1 2 7}(\mathbf{1 1 . 7 5 \% )}$ & $\begin{array}{c}\mathbf{7 5 3} \\
\mathbf{( 6 9 . 7 2} \%)\end{array}$ & $\mathbf{1 0 8 0}(\mathbf{1 0 0} \%)$ \\
\hline
\end{tabular}

\section{Zaključci}

Prezentirani rezultati potvrđuju našu glavnu hipotezu koja pretpostavlja da je kod učenika osnovnih i srednjih škola prisutno društveno neprihvatljivo ponašanje koje zahtijeva potrebnu intervenciju od strane stručnih lica.

1. U pogledu učestalosti problema u ponašanju učenika osnovnih i srednjih škola nije bilo statistički značajnijih razlika u kliničkom i graničnom ispoljavanju pojedinih opserviranih problema, osim u pojavi graničnih oblika internalizirajućih problema gdje učenici osnovnih škola pokazuju manju učestalost društveno neprihvatljivog ponašanja nego srednjoškolci. Stariji ispitanici su pokazali statistički značajno veće 
skorove za iskazane tipove ponašanja kao što su: nošenje vatrenog oružja, stupanja u intimne odnose sa različitim spolom, gledanje porno filmova, korištenje alkohola, korištenje duhana, laganje i bježanje sa nastave itd. Pregledom dobivenih rezultata moguće je prihvatiti prvu podhipotezu koja pretpostavlja da se sa povećanjem starosne granice povećava i pojavnost društveno neprihvatljivog ponašanja koje zahtijeva potrebnu intervenciju od strane stručnih lica;

2. Isto tako je moguće prihvatiti i našu drugu podhipotezu koja pretpostavlja da je društveno neprihvatljivo ponašanje više zastupljeno kod muških nego kod ženskih ispitanika, jer su u svim oblicima društveno neprihvatljivog ponašanja zastupljeniji dječaci, osim u tipu neovlaštenog snimanja u kojem su djevojčice u prednosti;

3. Istraživanje odbacuje našu treću podhipotezu prema kojoj su socijalne devijacije pretežno urbani fenomeni. Naime, nije utvrđeno da postoji povezanost društveno neprihvatljivog ponašanja koje se manifestuje u: saučesništvu u deliktu, krađi, tihoj agresivnosti, u pogledu nedozvoljenog snimanja, slanja okrutnih prijetnji, ignorisanja, izrugivanja, korištenja duhana, alkohola i droge, kockanja - i varijable koja nas informiše o socijalnoj teritoriji stanovanja maloljetnika. Samo u varijablama koje se odnose na laž i stupanje učenika u intimne odnose sa različitim spolom je utvrđena je statistički značajna razlika. Naime, maloljetnici iz urbanih sredina ispoljavaju veći stepen ovih radnji u odnosu na maloljetnike iz ruralnih sredina;

4. Na temelju rasprave o utjecaju izvanobiteljski faktora, utvrđeno je da sociodemografska obilježja kao što su zaposlenost, obrazovanje roditelja, materijalni status, tip i veličina porodice, ne utječu na pojavu društveno neprihvatljivog ponašanja. Dakle, možemo zaključiti da nije potvrđena ni četvrta podhipoteza u kojoj smo pretpostavili da izvanobiteljski faktori utječu na pojavu društveno neprihvatljivog ponašanja;

5. Uz pomoć multifaktorske analize podataka zaključujemo da intraobiteljski faktori imaju veoma veliki utjecaj na kompleksnost disocijalnih i asocijalnih oblika ponašanja. Najveći utjecaj ima roditeljski stil u odgoju, zatim odsustvo kontrole roditelja, smanjen obim i kvaliteta komunikacije sa djetetom. Ovi faktori su prikazani kao značajni prediktori koji se dovode u vezu sa pojavom društveno neprihvatljivog ponašanja maloljetnika. $\mathrm{Na}$ osnovu dobivenih rezultata potvrđena je naša 
peta podhipoteza u kojoj smo pretpostavili da intraobiteljski faktori utječu na ponašanje maloljetnika;

6. Kanoničkom korelacijskom analizom među varijablama pretrpljenog nasilja i društveno neprihvatljivog ponašanja tipa krađe s napadima, seksualnog nasilja, korištenja hladnog oružja, korištenja droga, bježanja sa nastave, ulaska u intimne odnose sa različitim spolom i korištenja alkohola, utvrđena je statistički značajna korelacija, što potvrđuje i našu šestu podhipotezu - da pretrpljeno nasilje ima za posljedicu poremećaj ponašanja kod učenika.

Iako mnogi znanstvenici tvrde da je porodica najodgovornija za razvoj djeteta, jer ima utjecaj na njega tokom cijelog života, ne treba zanemariti ni druge agense kao što su vršnjaci, mediji i način korištenja slobodnog vremena, koji svakako doprinose negativnom razvoju i poremećaju ponašanja. Dobiveni rezultati u apsolutnim i relativnim frekvencijama udjela ispitanika s pojedinim oblicima poremećaja u ponašanju, u promatranim subuzorcima pokazuju da $62 \%$ maloljetnika nekorisno provodi slobodno vrijeme. Unatoč određenim nedorečenostima i manjkavostima u praćenju stanja rizičnog ponašanja kod maloljetnika, prikazano stanje i kretanje mora biti dovoljan poticaj za pronalaženje adekvatnih strategija prevencije poremećaja u ponašanju djece i mladih. Praksa pokazuje, a iskustvo uči, da dobro istraženi razlozi i motivi koji potiču maloljetnike na takvo ponašanje mogu znatno utjecati na pravilnu dijagnostiku koja će dati smjernice nastavnicima, vaspitačima i drugim djelatnicima za adekvatne odgojne i korektivne mjere. Provedene analize i rezultati ovog istraživanja poslužit će za elaboraciju moguće predikcije ponašanja djece i mladih u određenim fazama odrastanja, na osnovu kojih se mogu planirati preventivne mjere u cilju suzbijanja devijantnih oblika ponašanja. Sljedeća sekcija upravo govori o preporukama rada sa roditeljima, djecom i nastavnicima koje mogu biti odgovor na početna rizična ponašanja djece za razliku od intervencije koja slijedi na kraju procesa razvoja devijantnosti.

\section{Preporuke}

Rezultati istraživanja pokazuju da je kod učenika osnovnih i srednjih škola prisutno društveno neprihvatljivo ponašanje koje može da se smanji u koordinaciji sa više stručnih timova i institucija koje pripadaju istim ili različitim službama (ministarstvima). Naime, bez obzira na dosadašnje pozitivne rezultate u prevenciji društveno neprihvatljivih 
oblika ponašanja, i dalje je potrebno raditi na međusektorskoj suradnji i konkretizaciji programskih aktivnosti. U ovoj sekciji izdvojit ćemo nekoliko preporuka koje mogu pomoći u radu sa roditeljima, nastavnicima, te učenicima osnovnih i srednjih škola, i u radu sa maloljetnim počiniocima krivičnog djela.

\section{$\mathrm{U}$ radu s roditeljima}

Suradnja sa roditeljima je ključni faktor preventivnog rada i suzbijanja nepoželjnih oblika ponašanja kod djece. Ona je potrebna kako bi se razmijenile informacije i ostvario odnos povjerenja koje će porodici pomoći u odgoju njihove djece i to na način da roditelji:

a. razviju osjećaj empatičnosti i bliskog odnosa sa svojom djecom koji se zasniva na uzajamnom razumijevanju,

b. podržavaju i ohrabruju svoju djecu kada je to potrebno, ali isto tako da ih uče da ne budu zavisni o roditeljima,

c. budu modeli prihvatljivog ponašanja svojoj djeci,

d. koriste adekvatne metode sankcionisanja nepoželjnih oblika ponašanja i nastoje da se isto ne ponovi,

e. upoznaju djecu sa posljedicama nasilja koje žrtva doživi, kao i sankcijama kojim podliježu počinioci nasilja,

f. prihvate svoje dijete i daju mu priliku da popravi svoje ponašanje,

g. razviju sposobnosti i vještine za prepoznavanje i uspješno rješavanje problema sa kojima se njihovo dijete suočava,

h. prate pohađanje nastave, školski uspjeh i vladanje svog djeteta putem redovnih odlazaka na roditeljske sastanke i informativne razgovore sa razrednim starješinom,

i. kontrolišu i ograniče vremensko korištenje Interneta, gledanje filmova i općenito sadržaja koji obiluje nasiljem,

j. pažljivo prenose informacije o izvršenju nekog kriminalnog djela, izbjegavanje detaljnog opisa brutalnog čina. 


\section{U radu s učenicima osnovnih škola}

Uzimajući u obzir da su trenutni nastavni planovi i programi u osnovnim školama preobimni, te da onemogućavaju kvalitetnu provedbu slobodnog vremena, u radu sa učenicima se mogu realizirati slijedeće aktivnosti, čime bi se otvorio put usvajanju socijalnih vještina, znanja i sposobnosti potrebnih za siguran rast $i$ razvoj djece kao dio cjeloživotnog učenja:

a. edukacija djece o načinu reagiranja u slučaju da budu predmet fizičkog ili psihičkog nasilja,

b. radionički pristup u radu sa djecom koji potiče otvoren razgovor o problemu nasilja među vršnjacima i načinima njegove prevencije,

c. uspostavljanje dječijih klubova i omladinskih centara gdje bi djeca i mladi mogli kvalitetno provoditi svoje slobodno vrijeme, ali $\mathrm{i}$ edukovati se o mehanizmima zaštite od nasilja među djecom,

d. u redovnom odgojno-obrazovnom procesu neophodno je raditi na razvijanju socijalnih vještina kod učenika koji su usmjereni na unaprjeđenje komunikacijskih vještina, jačanje samopoštovanja, slike o sebi, razvoj suradnje i tolerancije, suosjećanja, prijateljstva, upoznavanje vlastitih potreba te učenje konstruktivnog $\mathrm{i}$ asertivnog rješavanja problema,

e. jačati dječije kapacitete da se mogu suprotstaviti osobi koja čini nasilje i da je prijavi. Institucija školskog policajca je vrlo korisna ideja u ohrabrivanju prijave nasilja, s tim da se dodatno edukuju školski policajci kako bi dobili više informacija o problemima sa kojima se susreću djeca školskog uzrasta i efikasnim načinima njihovog rješavanja.

\section{U radu s učenicima srednjih škola}

Srednje obrazovanje predstavlja etapu u rastu i razvoju mladih kada moraju riješiti mnoge životne zadatke u raznim područjima i postići određene rezultate. Iako u ovom periodu postaju emocionalno stabilniji, kod većine maturanata je prisutan osjećaj nesigurnosti zbog moralnog gledišta i shvaćanja da nakon završetka srednje škole treba da nastave sa školovanjem ili da se zaposle. Složena ekonomska i politička situacija u zemlji onemogućava upis željenog fakulteta ili pronalazak adekvatnog zaposlenja. Uglavnom, većina adolescenata završi na crnom tržištu rada, 
a nije rijetka pojava da se bave ilegalnim radnjama kako bi sebi priuštili novac za život ili vanrednu naobrazbu. U cilju ublažavanja ovog problema i smanjenja nepoželjnih oblika ponašanja kod mladih, mogu se poduzeti slijedeći koraci:

a. u okviru funkcionisanja srednjih stručnih škola potrebno je razviti suradnju sa poslodavcima kako bi se učenicima obezbijedila adekvatna praksa (razmotriti mogućnost poreskih olakšica za poslodavce koji obezbjeđuju praksu, što zahtijeva i kasniji monitoring u cilju kontrole izvršenja i kvaliteta prakse),

b. u programe srednjih škola potrebno je uvrstiti i kratak kurs o osnovnim karakteristikama i funkcioniranju tržišta rada i planiranju poslovne karijere,

c. sistem pomoći u profesionalnoj orijentaciji treba da bude dostupniji i prilagođeniji učenicima, što se može ostvariti kroz razgovore sa psiholozima, testiranja, kroz organiziranje radionica ili projekata koji bi kombinirali rad, usavršavanje i razvoj ličnih vještina.

\section{U radu s nastavnicima}

Savremena škola traži nove, kompetentne nastavnike koji će osigurati dobru komunikaciju sa stručnim suradnicima, roditeljima i učenicima kako bi se smanjio stepen prisustva društveno neprihvatljivog ponašanja kod učenika. Obrazovni sektor treba da obezbijedi nastavnom kadru slijedeće:

a. stvoriti poticaje i mogućnosti za kontinuirano stručno usavršavanje nastavnog osoblja putem seminara, treninga, supervizija, sudjelovanja u projektima, savjetovanja u cilju obezbjeđenja kvaliteta nastavnog procesa,

b. adekvatan sistem praćenja i rane identifikacije svih oblika nasilja koje učenici ispoljavaju u školi. Neophodno je uspostaviti trajnu evidenciju kroz kartoteke u kojima bi se formirala baza podataka sa žrtvama nasilja i počiniteljima. Ovaj proces treba da bude monitorovan od strane stručnih radnika u školama i drugim institucijama u kojima borave djeca. Izuzetnu pažnju treba obratiti slučajevima seksualnog uznemiravanja, kako u odnosu odraslih prema djeci, tako i u odnosima među vršnjacima. Posebnu suradnju, 
kada je riječ o identifikaciji ovog oblika nasilja, je potrebno razviti između policije, škole, sudova i centara za socijalni rad,

c. senzibilizaciju u praćenju razvoja i uslova u kojima žive djeca kako bi se pravovremeno preduzele mjere za otklanjanje teškoća u razvoju djeteta, naročito poremećaja u njegovom društvenom ponašanju. $O$ tome je neophodno redovno informisati nadležnu zdravstvenu ustanovu, kao i nadležni centar za socijalni rad,

d. nastavnici moraju biti u toku, ne samo sa novim dostignućima u okviru njihovog predmeta, nego i sa novijim istraživanjima koja se tiču razvoja djeteta i novijim pristupima u obrazovanju,

e. razviti nove metode ocjenjivanja kako bi nastavnici mogli dobiti povratnu informaciju o onome što su učenici zaista razumjeli i naučili,

f. poticati na razvoj škole u otvorenom sistemu - organizirati edukativne, kulturne i rekreativne sadržaje za ispunjavanje slobodnog vremena učenika u saradnji sa roditeljima i lokalnom zajednicom.

\section{U radu sa vladinim i nevladinim organizacijama}

Najučinkovitija mjera u sprječavanju maloljetničkog prijestupništva jeste prevencija. U preventivne aktivnosti valja uključiti školu, socijalnu i zdravstvenu službu, vjerske institucije, nevladin sektor i druge progresivne društvene snage koje se brinu o djeci i mladima. Javnost treba educirati i senzibilizirati za problem u kojem su i sami počinioci krivičnog djela često izloženi bezobzirnom psihičkom i fizičkom nasilju, brutalnom premlaćivanju i zlostavljanju od vlastitih roditelja, članova obitelji i osoba kojima je počinjena šteta. U preventivnom radu predlažemo slijedeće mjere:

a. na nivou primarne prevencije, ponuditi programe resocijalizacije koji bi motivirali djecu i maloljetnike rizičnog socijalnog ponašanja da, uz stručni nadzor osoba, pohađaju radionice, igraonice ili organizirane oblike zajedničkog druženja,

b. na nivou kurativnog rada, diferenciran stručni rad sa djecom i maloljetnim izvršiocima krivičnih djela, odnosno djecom i maloljetnicima koji manifestuju druge oblike poremećaja u ponašanju. Stručni rad treba da ima individualni pristup baziran na praćenju individualiziranih planova i programa, 
c. konstantna suradnja socijalnih radnika i predstavnika lokalne zajednice,

d. međusektorska saradnja između škole, zdravstvene ustanove, policije, tužilaštva, suda, nevladine organizacije, centra za socijalni rad i porodice maloljetnog počinitelja krivičnog djela,

e. motiviranje sugrađana da prijavljuju prekršaje/delikte maloljetnih počinilaca krivičnih djela,

f. formiranje mreže volontera, tzv. Street workers, koji bi direktno radili na ulici sa djecom koja nisu pod nadzorom roditelja,

g. da se postupak prema maloljetnicima okonča u što kraćem vremenu i uz što manji broj ročišta na kojima bi se utvrdile sve neophodne činjenice i dokazi,

h. ohrabriti porodicu da smogne snage da otvoreno, jasno i odlučno razgovara o problemu koje ima sa svojim djetetom i da traže pomoć od socijalnih i zdravstvenih službi, savjetovališta za djecu, mlade, porodicu i brak kako bi se poduzele potrebne mjere zaštite, te kako bi se pomoglo djetetu i roditeljima,

i. uticati na to da se vrši kontrola informacija na televizijskim programima, radiju i novinama, u cilju zaštite identiteta maloljetne osobe kao počinioca krivičnog djela.

Iz svega gore navedenog može se zaključiti da je veoma bitno raditi na prevenciji i rješavanju problema društveno neprihvatljivih oblika ponašanja kod djece i omladine. Iako je istraživanje obuhvatilo dobnu skupinu od 13 do 18 godina, preventivni rad sa djecom treba otpočeti mnogo ranije. Naime, roditelji, odgajatelji u vrtiću i učitelji trebaju djecu učiti da probleme rješavaju nenasilno, razgovarati sa njima na način da shvate ono što im se savjetuje, postavljati čvrste, konzistentne granice prilagođene uzrastu djeteta. Želim istaći da se ovom problemu treba pristupiti interdisciplinarno kako bi zajednica prepoznala potrebu rada na suzbijanju faktora koji omogućavaju njegovo nastajanje i širenje.

\section{Literatura}

1. Ajduković, D.: Socijalna rekonstrukcija zajednice, Psihološki procesi, rješavanja sukoba i socijalne akcije, Društvo za psihološku pomoć, Zagreb, 2003. (str. 218-220)

2. Američka psihijatrijska udruga DSM-IV: Dijagnostički i statistički priručnik za duševne poremé́aje s MKB-10 siframa. Jastrebarsko: Naklada Slap, 1998. 
3. Andrilovič, V., Čudina, M.: Psihologija učenja i nastave, Školska knjiga, Zagreb, 1985. (str. 152)

4. Aronson, E., Wilson, T. D.,\& Akert, R. M.: Social psychology. NJ: Prentice Hall, Upper Saddle River, 2002.

5. Bajrić, M., Stevanović,M.: Direktor, pomónik i pedagog u školi, R\&S, Tuzla, 1999. (str. 218.)

6. Bandura, A.: Imitation of film-inedited aggressive models. In: Journal of Abnormal and Social Psychology,66, p. 3-11, 1963.

7. Goleman, D.: Socijalna inteligencija, nova nauka o ljudskim odnosima Geopoteka, Beograd, 2007. (str. 138, 278)

8. Hartmut von Henting: Die Schule neu denken:Eine Ubung in praktischer, Munchen, 1993.

9. Healy W., Alper B.: Criminal Youth and the Borstal System, New York, 1941.

10. Henting, H.: Humana škola, EDUCA, Zagreb, 1997. (str. 11)

11. Hercigonja, D., i autori: Hiperaktivno dijete, uznemireni roditelji i odgajatelji, Naklada Slap, Jastrebarsko, 1999. ( str. 28,29)

12. Hinsaw, S. P., Zupan, B. A: Assessment of antisocial behavior in children and adolescents. U: D. M. Stoff, J. Breiling, J. D. Maser (ur.), Handbook of Antisocial Behavior (str. 36-50), New York: John Wiley \& Sons Inc. 1997.

13. Hoffman, L.: The family life cycle and discountinuous change, in B. Cartter and M.McGoldrick (Eds.)The changing family life cycle, Boston, Allyn Bacon, 1989.

14. Hrnjica, S.: Opšta psihologija sa psihologijom ličnosti, Naučna knjiga nova, Beograd, 2005. ( str. 111)

15. Jašović, Ž.: Kriminologija maloljetničke delinkvencije, Beograd, 1978.

16. Kastratović, Ž.: Adolescentna kriza. Psihijatrija danas, VIII, 1976. (str. 3-4)

17. Konig, E., Zedler, P.: Teorije ₹nanosti o odgoju, EDUCA, Zagreb, 1998. (str. 59).

18. Kučukalić, A.: Liječenje psibičkih poremé́aja uslovljenih stresom, Sarajevo Publishing, Sarajevo, 1998. ( str. 35).

19. Kukić, S.: Sociologija, teorije društvene strukture:Sarajevo, 2004. (str. 382, 388, 390-396)

20. Kundačina, M., Brkić, M.: Pedagoška statistika,Učiteljski fakultet u Užicu Univerzitet u Kragujevcu, Užice, 2006. (str. 47-54)

21. Mavrak, M.: Agresivnost kao odgojni problem, Zbornik radova sa okruglog stola i seminara, Zenica, 1999. (str. 131)

22. Muminović,H. (2000.): Moguínosti efikasnijeg ǚenja u nastavi, DES, Sarajevo (str. 47)

23. Mužić, V. (1999.): Uvod u metodologiju istrą̌ivanja odgoja i obrazovanja, EDUCA, Zagreb (str. 43) 
24. Ostojić E., Kovač, B. (1999.): Ne živjeti s nasiljem, Drugi pogled 2, Medica, Zenica, (str. 77)

25. Pašalić-Kreso, A. (2004.): Koordinate obiteljskog odgoja; Filozofski fakultet u Sarajevu Sarajevo, (str. 323)

26. Philipps,S. (1998.): Montesori priprema za život, odgoj neovisnosti $i$ odgovornosti, Naklada Slap, Zagreb, (str. 74.)

27. Piage, J. (1948.): The moral development of the child, Glencon, Free Press.

28. Piaget, J. (1969.): Le jugement moral chez l'enfant, Paris,

29. Plut, D. ; Marinković, LJ. (1994.): Konflikti i šta sa njïm, Priručnik, treća knjiga, Kreativni centar, Beograd ( str. 12)

30. Praktikum projektivni predstava ideja za grupi rad, za kreativniji $i$ zajednički rad ǔcenika $i$ nastavnika: (2002.) MDD-Multidisciplinarno društvo za unaprjeđenje mentalnog i socijalnog zdravlja, Sarajevo

31. Savić, J. i suradnici (2005.): Djeca o sebi, Istraživanje o položaju djece u porodici, školi i okruženju ( str. 21, 29)

32. Stevanović, M. (1998.): Metoda recepcije u nastavi, R\&S, Tuzla, (str. 21)

33. Stoiljković, S. (1986.): Psibijatrija sa medicinskom psibologijom, Medicinska knjiga, Beograd-Zagreb (str. 145)

34. Šošić, I. ( 2004.): Primijenjena statistika; Školska knjiga, Zagreb

35. Tadić, N. (2006.): Psibijatrija djetinjstva i mladosti, Naučna KMD, Beograd (str. 354)

36. Tadić, N. i suradnici (2004.): Psihoanalitička psihoterapija djece i mladib; Naučna KMD, Beograd (str. 99, 354, 433)

37. Tomić, R. (2005.): Komunikacija sa djecom delinkventnog ponašanja, DENFAS, Tuzla, (str. 53)

38. Uzelac, M. (1999.): Za damire $i$ nemire, prema nenasilju, Priručnik miroljubivog rješavanja problema u školi i ublažavanje trauma, Zagreb (str. 67)

39. Veljković,V. (2002.): Hiperaktivnost, Priručnik za inkluzivnu nastavu, HO Duga, Sarajevo, ( str. 51)

40. Zvonarević, M. (1981.): Socijalna psihologija. Školska knjiga, Zagreb, (str. 642)

41. Žužul, M. (1989.): Agresiono ponašanje - Psihologijska analiza. Radna zajednica Republičke konferencije Saveza socijalističke omladine Hrvatske, Zagreb

42. Winkel, R. (1994.): Djeca koju je teško odgajati, EDUCA, Zagreb (str. 63)

43. Wood, D. (1995.): Kako djeca misle i ǔ́e, Zagreb 
Nusreta Kepeš, PHd

\section{ETIOLOGY OF DISORDER BEHAVIOR WITH ADOLESCENTS IN BIH}

\section{APSTRACT}

B\&H society in recent years has been faced with emergence of sociallyunacceptable behavior in juveniles that is taking bigger and bigger proportions with each day. This paper is a small and modest contribution aimed to clarify this problem by analysing its occurrence and etiology. Essance of this reasearch is based on using the established factual sittuation in schools to further analyse, systematize and make comparisons of casual connection factors that triggered this socially-unacceptable behavior. Results can be used to find adequate strategies that would give permanent and efficient results that help prevent behaviour disorders with elementary and highschool students. 


\section{الأستاذة الدكتورة نوصرتا كيبيش}

\section{علم أسباب اضطرابات سلوكية لدى المراهقين في البوسنة والهرسك}

\section{الخلاصية}

يواجه المجتمع البوسنوي في الآونة الأخيرة ظهور سلوك غير مقبول اجتماعياً

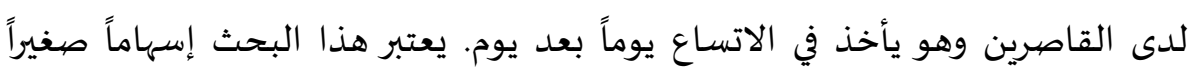

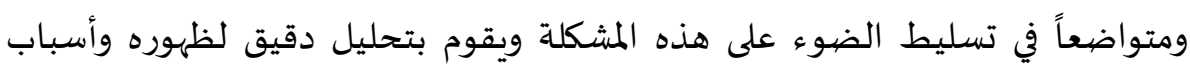

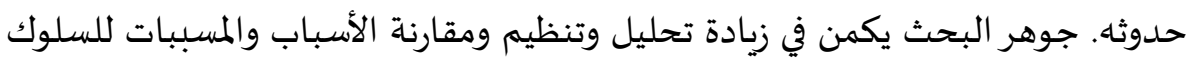

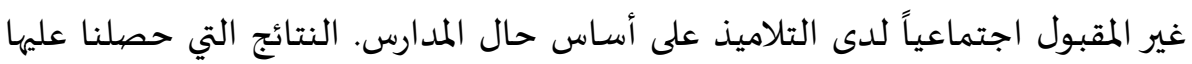

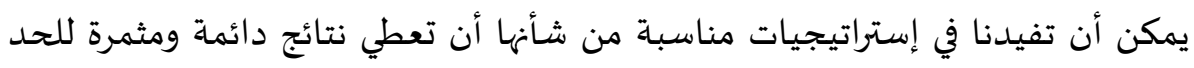
من انتشارظهور السلوك غير المقبول اجتماعياً لدى تلاميذ المدارس الابتدائية والثانوياة. 